\title{
Push or pull motivation? A study of migrant women entrepreneurs in UAE
}

\author{
Julie Vardhan* \\ School of Business, \\ Manipal University, \\ P.O. Box 345050, Dubai, UAE \\ Email: joulevardhan@gmail.com \\ *Corresponding author
}

\section{Supriya Bohra, Aaminah Abdullah, Kavitha Thennarasu and Sathya K. Jagannathan}

\author{
Manipal University, \\ P.O. Box 345050, Dubai, UAE \\ Email: supriya_bohra@yahoo.com \\ Email: aamiabdulla@hotmail.com \\ Email: kavi.arasu92@gmail.com \\ Email: sathyakj2407@gmail.com
}

\begin{abstract}
The study intends to find the motivational factors and personality characteristics of migrant women entrepreneurs in UAE. While a number of research argue that women have been pulled into entrepreneurship for economic independence, other studies consider that women have been pushed to entrepreneurship due to non-availability of employment opportunities in other areas. To date, existing research on 'push-pull' has not been considered in the context of migrant women entrepreneurs in UAE. Drawing on survey and interview with 29 'migrant' (also called 'expatriate') women entrepreneurs in UAE, this exploratory study examines the motivational factors and entrepreneurial traits of success for the expatriate women. Data are collected over a period of one year, and consists of a survey through a questionnaire and interviews with 13 of the entrepreneurs to understand the entrepreneurial journey. The findings suggest the importance of push as well as the pull factors, and the influence of the personal characteristics in the formation of a new business. By exploring the motivations and characteristics that impact the business performance of women migrant entrepreneurs, we aim to enrich understanding on migrant women entrepreneurship in UAE.
\end{abstract}

Keywords: migrant entrepreneurs; women; personalities; push-pull motivations; UAE.

Reference to this paper should be made as follows: Vardhan, J., Bohra, S., Abdullah, A., Thennarasu, K. and Jagannathan, S.K. (2020) 'Push or pull motivation? A study of migrant women entrepreneurs in UAE', Int. J. Family Business and Regional Development, Vol. 1, No. 1, pp.8-24. 
Biographical notes: Julie Vardhan is an Assistant Professor at School of Business, Manipal University, Dubai. For more than over a decade, she has been involved in facilitating learning in the areas of entrepreneurship and marketing. She is pursuing her DBA at SMC University Switzerland. Her research interests include entrepreneurship and higher education. She is particularly interested - and the orientation of her teaching - is in understanding entrepreneurial attitude both at the individual and firm level to build better productivity and growth.

Supriya Bohra received her MBA from Manipal University, Dubai. During her MBA, she picked up interest in youth empowerment and co-founded a CSR initiative, SheDares, that caters to young women in the region. She is an ardent supporter of gender equality and intends to make a difference in the current plight of women in the society. Her research interests include migrant women entrepreneurship, women empowerment and feminism issues in the Middle East region.

Aaminah Abdullah is an IT and MBA graduate from Manipal University, Dubai. She has a penchant for programming codes and published a research paper on animation in e-learning on behalf of Undergraduate Research Conference Dubai in 2010. A firm believer in gender equality and human rights globally, her research interest lies in coding, women empowerment, solutions for gender discrimination and bridging the gender gap globally. She draws her motivation from autobiographies and the women back home.

Kavitha Thennarasu received her Electronics and Communication Engineering degree and MBA in Finance from Manipal University, Dubai. She is currently pursuing CIMA. She has a keen interest in numbers and keeps herself updated about the current market scenario. Her research interest lies in understanding the barriers for women to select finance as a business concentration and to bridge the gap between men and women in investment and banking.

Sathya K. Jagannathan received her BE in Information Science and MBA from Manipal University, Dubai. Prior to beginning the MBA program, she has worked as a CRM Consultant for projects involving retail and airline loyalty program. Her main research interests are effective end-to-end marketing and psychological factors that drives customer decision-making. She has also developed interests towards how women should explore, innovate and bring changes in today's challenging environment that would turn into a unique professional model of practice.

\section{Introduction}

Entrepreneurship as a driver of economic development has led to an increased focus by nations to develop entrepreneurship, especially women entrepreneurship (Minniti and Naudé, 2010; Langevang and Gough, 2012). Although entrepreneurship has been traditionally associated with men, in recent years the number of businesses owned by women have grown more rapidly than men's business around the world (Minniti and Naudé, 2010; Langevang and Gough, 2012). The size and growth of this phenomenon has attracted significant attention from academics, practitioners and policy makers (Ehigie and Umoren, 2008). While a majority of the extant studies have been undertaken to 
examine factors that affect women entrepreneurs in developed markets, a limited number of studies have been undertaken to investigate these factors in the Arab world in general and in the Middle East region in particular (Dechant and Al-Lamky, 2005).

With globalisation integrating businesses, processes, communication and people, it is found that the migrants or expatriates form a significant section of the population, especially in UAE. Many of these migrants have created successful business ventures in UAE exemplifying the concept of migrant entrepreneurship. The phenomenon of 'migrant entrepreneurship' refers to business activities undertaken by migrants of a specific socio-cultural and ethnic background (Sahin et al., 2009). While entrepreneurship research is focused on a number of motivational factors, there is little research that explains the motivations behind creation of successful enterprise in UAE, especially by migrant women entrepreneurs.

Motivation or drive is the inherent force which pushes the individual towards starting a new venture, but there is a considerable debate on the pull and push motivational factors on entrepreneurship. What are the factors that push women to be entrepreneurs? Or are there factors that pull them towards entrepreneurship? As in the study by Essers and Benschop (2007, 2009), we are taking the issue of subjectivity of entrepreneurship to include the identity categories of gender and nationality. The purpose of this paper is therefore to identify factors that motivate the expatriate women to start business and become self-employed, and further to identify the personality characteristics that were the enabling factors for their entrepreneurial decision. Applying a blend of theoretical and applied research, we will explore the entrepreneurial phenomenon for this segment of population. We will begin with first discussing some key characteristics of the UAE context; to understand the uniqueness and necessity of studying women migrant entrepreneurship in this country. In the next section we will study the theoretical background on migrant women entrepreneurship, the personality characteristics and the motivational factors. Next we will discuss the methodology and the rationale behind the research method after which we will detail the findings and interpretation, with the last section being the conclusion and future research areas.

\section{The UAE context}

The UAE is considered one of the most progressive of GCC states. The World Bank's 2016 Doing Business Report, ranks the United Arab Emirates as 31st on the overall Ease of Doing Business, out of 189 economies worldwide (World Bank, 2016). The UAE recognises and embraces the economic and social benefits of diversity and women are viewed as partners in achieving sustainable development (UAE Interact, 2015a). According to the 2013 WEF Global Gender Gap Report, the UAE is the only Arab country in the MENA region that has fully closed the educational attainment gender gap: the UAE ranked sixth (out of a total of 136 countries) on the report's literacy rate indicator and seventh on enrolment in the primary education indicator. The UAE has an impressive $90 \%$ literacy rate in women, slightly higher than men, while $77 \%$ of the women in the UAE seek higher education, which is $24 \%$ more than men (UAE Interact, 2015b).

The UAE Government has been taking initiatives to bring out entrepreneurial trends amongst the young and educated women. For instance, The Dubai Business Women's Council partnered with MasterCard and launched Ro'Ya, an initiative to support women 
entrepreneurship in UAE. The main objective is to enable a platform to share knowledge among the women entrepreneurs and also build strong network within the region (Gulf Business, 2014). Similarly, The Sharjah Business Women's Council was established to support the integration of women in all economic activities. The council offers women wider fields to develop their personal skills, opportunities for more creativity and improvement of performance in their professional and business endeavours. Moreover the council contributes in developing women-owned businesses through mentorship programmes by economic and finance experts. The National Strategy for the Advancement of Women which was established in 2002 affirmed its strategic purpose "to activate the role of women and their positive participation" (UAE Interact, 2015b). Women entrepreneurs are also supported by, for instance, the Mohammed Bin Rashid Establishment for Young Business Leaders in Dubai (MREYBL). The establishment of the Women's General Union in 1973, which gives equal rights to women on all fronts, has been achieved in accordance with the Islamic principles of equal rights and duties. One of the most important accomplishments for the UAE women is the approval of the law that secures women's constitutional rights - the right to work, social security, possession, managing their business and finances. The law has also secured their education, health care, social services, equal salary as their male counter parts and maternity leave. These national policies, social structure and economic policies of the UAE are meant for the women residents here including the expatriate women entrepreneurs. Do these facilitations pull the expatriate women towards entrepreneurship? This was one of the questions this research seeks to answer.

UAE is also unique because of its population composition-providing a compelling case for our study. UAE represents more than 200 nationalities within the country with 7.8 million migrants (UAE Interact, 2013). About $70 \%$ of its population are expatriates. The migrants or expatriates form a significant section of the population of UAE. Many of these migrants have created successful business ventures in UAE exemplifying the concept of migrant entrepreneurship. The phenomenon of 'migrant entrepreneurship' refers to business activities undertaken by migrants of a specific socio-cultural and ethnic background (Sahin et al., 2009).

A review on women and migrant entrepreneurship and the push-pull motivations are given below to understand the identity basis and the concepts of motivation.

\section{Theoretical background}

\subsection{Women entrepreneurship}

The mainstream entrepreneurship literature conceptualises entrepreneurship as a neutral phenomenon with entrepreneurs demonstrating certain characteristics or traits. Majority of the literature also conceives of entrepreneurship generally as a gendered (male) process (Essers and Tedmanson, 2014). Gender being the personal and societal system by which sense is made of biological differences between men and women (Essers and Benschop, 2009) that also resulted in differences in their approaches. Some of the early studies on women entrepreneurship (Cook, 1982; Schwartz, 1976), that explored why females became entrepreneurs found the response given by them as similar to their male counterparts such as need for independence and need for achievement (quoted in Brooke and Margaret, 1998). Another study by Hisrich and Peters (1996) also reported no 
difference in personal goals such as independence, achievement and economic necessity between the male and female entrepreneurs.

However, it was Fagenson and Marcus (1991) who discovered that female entrepreneurs were different from the male entrepreneurs and had a much broader vision involving their desires including total quality and world peace. Since then a number of studies have focused on the characteristics, motivations and challenges faced by women entrepreneurs in different regions of the world. A study by Roomi and Parrot (2008) found that women entrepreneurs do not enjoy same opportunities as men due to number of deep-rooted discriminatory socio-cultural values and traditions. There are also a number of entry barriers for female entrepreneurs for instance access to capital, information technology, training, agency assistance and social networks (Klyver and Terjesen, 2007; Hwang et al., 2008).

While some studies found apparent differences between the male and female entrepreneurs in their internal attributions (Gatewood et al., 1994), a recent study has shown that both men and women can be successful entrepreneurs as they share similar motivations, access similar funding sources, and face similar challenges (McGrath Cohoon, 2010). Some of the other studies on women entrepreneurship are by Mani (2011) which found among 300 women entrepreneurs in India that the personality traits are related to the psychological aspects of the entrepreneurs. In the study a significant correlation was found between decision making ability, economic motivation, managerial ability, problem recognition and willingness to take risks with entrepreneurship. A few more studies based in India (Mani, 2011; Chavan, 2011), countries in the African continent (Madichie, 2009), and in UAE (Haan, 2004; Goby and Erogul, 2011) respectively found that the motivation and challenges of these women entrepreneurs are similar.

\subsection{Migrant entrepreneurship}

One of the other identity constructs apart from gender is the national identity. People have multiple, inter-related and evolving selves (Sardar, 2005) and one of the identities along with gender is the national identity, values, norms, rituals and customs with which one identifies. Nationality gives an identity to the individual and when people migrate to other nations they find themselves identifying with their nationality or ethnicity against the more homogenised community members of the host nation. According to Essers and Benschop (2009) ethnicity is an ideological construct dividing people into inclusionary and exclusionary categories against some homogenised community. The ethnic identities are created by incorporating symbolic elements of cultural practices, nationality, language or religion (Sardar, 2005).

Individuals who have migrated from their home country to establish business in the host country are called as migrant entrepreneurs and these entrepreneurs may focus on their ethnic market niches for their business. Reviewing the literature on migrant entrepreneurship Sahin et al. (2009) refer to Jenkins' (1984) three basic models of migrant entrepreneurship:

1 the economic opportunity model

2 the culture model

3 the reaction model. 
The economic opportunity considers the entrepreneurs rely on the market for opportunity, the cultural model assumes some cultures predispose group members towards successful pursuit of entrepreneurship and the reaction model assumes that the migrants take up selfemployment as a push from the environment where they are not able to find avenues in the mainstream society.

The study by Osirim (2008) about transnationalism of the women African immigrants in the USA and how they contribute to the family as well as their African-American community finds that while they are transnational, they differ from their male counterparts in their commitment to family and community. While a number of studies focused on women entrepreneurship, we did not come across studies on migrant women entrepreneurs, especially in the UAE and hence this study will be exploring this segment.

\subsection{Entrepreneurial characteristics and motivation}

One of the most important dimensions in entrepreneurship is the motivational factors that drive the entrepreneurs in their business. This goal-directed behaviour could be shaped by a number of factors ranging from personal, social, cultural, and economic to environmental. McClelland's (1961) theory of motivation classifies the entrepreneurs' motives based on three needs: the need for achievement, power and affiliation. The motivational factors, especially the psychological studies on entrepreneurship concentrate on studying who and why an entrepreneur is an entrepreneur, which is due to the trait or characteristics he may have intrinsically. Hence we are reviewing the characteristics and the motivating factors together.

The two approaches investigating the characteristics of entrepreneurs are the intrinsic environmental factors such as gender, birth order, marital status, role models and previous work experience (Aldrich, 1989; Brockhaus, 1982; Saffu, 2003), and the trait theory which emphasises on the personal traits and characteristics (Carland and Carland, 1993; Hansemark, 1998; Johnson, 1990; McClelland, 1961, Saffu, 2003; Kuratko, 2008; Sapuan et al., 2009) which views the entrepreneur as a person demonstrating traits such as vigour, energy, persistence and self-esteem. Personality characteristics of the entrepreneurs are formed by the interplay between the individual and the environment and the study by Brush and Hisrich (1991) found that majority of them were first born, married (71\%), had at least two children (55\%), aged between 31-41 years (48\%). Additionally $38 \%$ had their fathers as entrepreneurs and $50 \%$ of them also had their mothers who were employed (in Ramaswamy, 2013). While our study will highlight the intrinsic environmental charateristics aspect of the entrepreneurs, we will focus more on the personal traits and characteristics.

According to McClelland (1961), there are certain competencies of entrepreneurs, which are consistent in almost every country and which he identified as:

1 opportunity seeking and initiative

2 risk taking

3 demand for efficiency and quality

4 persistence

5 commitment to the work contract 
6 information seeking

7 goal setting

8 systematic planning and monitoring

9 persuasion and networking

10 independence and self-confidence.

Among the characteristics we will examine will be the:

1 need for achievement

2 locus of control

3 risk-taking propensity

4 self-confidence.

The need for achievement has been proposed by McClelland (1961) as a strong psychological force driving an entrepreneurial action. People who have high level of achievement motivation set challenging goals and endeavour to achieve them. They also have a strong desire to be successful and therefore take up the entrepreneurial path (Shaver and Scott, 1991).

The locus of control is a psychological factor that has been presumed to explain the success of entrepreneurs and differentiating them from non-entrepreneurs (Aldrich and Zimmer, 1986). It refers to a person's control over the events in one's life and if the individual perceives that achievement is a result of external factors or they have the control over their lives. The internal locus of control is associated with entrepreneur's attitude towards life, work behaviour and also firm performance.

The risk-taking propensity is a trait that has been used to distinguish entrepreneurs from non-entrepreneurs (Shane, 1996; Miner et al., 1989). It is the orientation of the entrepreneurs to take chances in uncertain decision making contexts. Milton (1989) asserts that entrepreneurs do not only operate in an uncertain environment but they eagerly undertake the unknown and willingly seek out and manage uncertainty. Studies have also found that this characteristic is dependent on the age, motivation, business experience and education of the entrepreneurs (Schwer and Yucelt, 1984).

The final psychological characteristic considered in this current study is self-confidence. It has been shown in studies such as those by Ho and Koh (1992) that entrepreneurs were found to have a higher degree of self-confidence relative to nonentrepreneurs.

\subsection{Push and pull motivation}

McClelland (1961) also suggests that, regardless of variations in economic development, entrepreneurs with high motivation will almost always find ways to maximise economic achievement. We are suggesting in this study that the higher degree of achievement, risk-taking ability, need for independence and high self confidence are the inner drive of an individual which can be classified as 'pull factors' of motivation. The 'pull' view considers self-employment as largely shaped by an individual's own choice and agency, with the individual seeking independence and opportunity (Hughes, 2003). 
The 'push' view considers individuals to be pushed towards entrepreneurship because of downsizing, restructuring, or other practices that does not allow the individual to join the mainstream employment models (Hughes, 2003). Higher percentage of women entrepreneurs are seen in the entrepreneurship literature characterised as 'necessity entrepreneurship' or push entrepreneurship whereas more number of male entrepreneurs come under the category of 'opportunities' or pull entrepreneurship. The percent of women entrepreneurs due to push factors is higher in countries where the general income per capita is low and where women have no other option for making a living. A survey conducted in Canada suggests that a vast majority of the individuals have been pulled into self-employment by a desire for independence with the majority citing 'entrepreneurial values' (such as independence, control over decisions and the challenge) when asked the main reason for becoming self-employed and only $21 \%$ have been pushed into self-employment [Delage (2002) cited in Hughes (2003)]. In the same study, Hughes (2003) also gives the example of surveys in USA of women business owners which indicates that push factors were not as important as pull factors and where relevant, related to gender barriers (such as the 'glass ceiling') rather than job loss or restructuring. Some studies in 1990s in developed country as Britain also found that many women take up self-employment due to economic necessity [MacDonald (1996) cited in Hughes (2003)]. In the present study through the insights of the women entrepreneurs we will try to understand the push or pull factors as the driving force for their enterprise.

\section{Methodology of the study}

The review of the literature by Salmenniemi et al. (2011) on existing studies on women's entrepreneurship and gendered practices of business in transition economies finds that most of the earlier research has focused on characteristics, their social networks, their challenges, and the role of institutional environment. UAE being a country attracting a large population of migrant entrepreneurs, the objective of the study was understanding the pull or push factors as drivers of motivation for the migrant women entrepreneurs. This study aims to identify the characteristics and driving factors that help these expatriate women start-up entrepreneurial business.

Drawing on survey and interview with 29 expatriate women entrepreneurs in UAE, this exploratory study examines the motivational factors and entrepreneurial traits of success for the expatriate women. Data are collected over a period of one year, and consists of a survey through an online questionnaire. A convenient random sampling technique has been adopted for collecting data both at the survey level and also subsequently at the interview stage. The women entrepreneurs were identified based on their migrant nature and the survey tried to understand the motivation that primarily caused them to start their own business. This survey was conducted over a period of one year, during October 2014 to November 2015. A qualitative method was then employed, by interviewing 13 of these entrepreneurs, with the interviews consisting of a narrative approach whereby the narrator could express their motivational factors and characteristics (McAdams, 1997). The interviews were semi-structured in nature with the duration varying from 20 minutes to an hour and direction and length of interviews were determined by the form of the emerging data. 
To analyse the data, we first tabulated all the results to describe the sample characteristics, and percentage analysis was done to show the number of entrepreneurs conforming to a particular factor. Apart from this, we also looked into the respondents accounts to understand their characteristics and motivations in their entrepreneurial journey.

\section{Analysis and interpretation}

As our objective of the study was related to understanding, rather than measuring (Oinas, 1999), we have tried to explore each of the characteristics and motivations given by the entrepreneurs. At the initial level of analysis, we have quantified the results on the 29 entrepreneurs further to which the insights given by the 13 entrepreneurs are used as supplements to add voice to the text and help categorise the data (Wolcott, 1990). The methodological techniques provided sufficient depth of data to allow a meaningful analysis of the entrepreneurial process in context, to explore their motivations and characteristics. It also helped us to understand if the motivations could be classified as push or pull as each entrepreneur had their own perception about these motives. Applying a blend of theoretical and applied research, we feel this methodology is justifiable as it helps in quantifying observations for a sample and further explores the themes on a representative group to understand the process better. We first tabulate our findings based on intrinsic environmental factors like age, nationality, education and marital status. In the next level we tabulate the personality traits or characteristics and finally the push or pull motivation is categorised. The analysis is interspersed with insights received from the entrepreneurs. This helps us in understanding the phenomenon as experienced and expressed by the women entrepreneurs.

\subsection{Intrinsic environmental factors}

The age group of the respondents was 21 years -40 years with the average age of the respondents being 35 years. All these women entrepreneurs have been settled in the UAE for more than five years on residence/sponsorship visa. A summary of their nationalities is mentioned in Table 1:

Table 1 Nationalities of the sample

\begin{tabular}{lc}
\hline Nationalities & Number of respondents \\
\hline Indian & 13 \\
South-east Asia & 5 \\
Africa & 5 \\
Trinidad and Tobago & 3 \\
Pakistan & 2 \\
USA & 1 \\
\hline
\end{tabular}

The entrepreneur's level of education has long been seen as a crucial factor in determining both actual entry into self-employment and the longer-term success of the business (Carter and Jones-Evans, 2006). The educational qualification of the respondents is shown in Table 2. 
Table 2 Educational attainment of migrant women entrepreneurs

\begin{tabular}{lc}
\hline Level of education & Percentage \\
\hline High school & $6 \%$ \\
Bachelor's degree & $80 \%$ \\
Masters/professional degree & $14 \%$ \\
\hline
\end{tabular}

Among those who had the bachelor's degree, they were either commerce or science background. Also it was interesting to see that among the respondents who had bachelor's and master's degree, $65 \%$ were keen on opening up a business based on their academic background.

One of the other findings was that $75 \%$ of the samples were married, with $60 \%$ having children.

The demographic characteristics across all the nationalities conforms to what the study earlier by Brush and Hisrich (1991) and later Simsek and Uzay (2009) had found earlier: a typical woman entrepreneur was the first born; hailed from a middle or upper class family; had a self-employed father; held a college degree; was married; had children; started their significant entrepreneurial career between the ages of 40-45; had previous experience in the venture; and were independent.

Overall, the women in the study were involved in a wide range of business areas, ranging from lifestyles, textiles, beauty, healthcare, education to social enterprise.

Table 3 Types of business respondents involved in

\begin{tabular}{lc}
\hline Type of business & No. of women entrepreneurs engaged \\
\hline E-business consulting firm & 2 \\
Printing press & 1 \\
Beauty parlour & 8 \\
Healthcare & 3 \\
Tuition centre & 2 \\
Social Enterprise & 4 \\
Interiors and furnitures & 5 \\
Textile business & 4 \\
& 29 \\
\hline
\end{tabular}

\subsection{Personality characteristics}

Ramaswamy (2013) suggests personality characteristics are crucial in running, establishing and maintaining any entrepreneurial activity. The respondents were asked to highlight the characteristics that are most common in business women from the UAE. Table 4 summarises the important characteristics given by the migrant women entrepreneurs. 
Table 4 Characteristics of entrepreneurs

\begin{tabular}{lc}
\hline & Percentage \\
\hline Need for achievement & $93 \%$ \\
Moderate risk taker & $80 \%$ \\
Self-confidence & $42 \%$ \\
Self-management (internal locus of control) & $59 \%$ \\
\hline
\end{tabular}

The questionnaire asked respondents to prioritise among a list of characteristics which they thought are important to entrepreneurs. It was also noted that women who seek to be their own boss and prefer their independence have a high need for achievement. $93 \%$ of the women who are entrepreneurs stated that being self-dependent and career-oriented was important. About $80 \%$ of the entrepreneurs said that they do not take huge risks without trying to minimise the after-effect. At the same time, intelligence regarding understanding people and their also being good in self-management was considered important for entrepreneurs by more than $59 \%$ of the target. These women believed that the performance and growth in the business largely depends on their decision making skills for which they considered themselves to be accountable, that which constitutes the internal locus of control, in the entrepreneurship literature.

Although the views expressed in Table 4 may not be atypical of entrepreneurs in general, what was interesting to note was that $80 \%$ of them indicated that they have mostly taken moderate risks by turning their interests/hobbies into business. While a majority of the respondents admitted that expertise in the similar field aids the business, it was not considered very important for the success of it. There were a few entrepreneurs, like the owner of the e-consulting business, who had taken considerable risk in starting the business.

Another interesting finding was that though most of these women had high need of achievement, self-confidence was only about $42 \%$. Majority of the women felt the education, training and business skills would help in increasing their self-confidence.

"Education and training would definitely help in reducing the time for business decisions as many are presently based on self-learning and discovery" commented one of the women entrepreneurs operating a beauty parlour.

\subsection{Motivational factors}

To understand the level of push or pull motivational factors, respondents were asked to point the reasons for becoming self-employed. As mentioned in the research by Hughes (2003) instead of selecting just one response or the 'main reason' for their self-employment, respondents were asked for multiple responses; if they felt there were more than one reason for their entrepreneurial endeavour.

The personality characteristics of the women entrepreneurs as described in the last section are further elaborated as the pull factors of motivation, where the intrinsic motivation of the individual drives her towards entrepreneurship. Table 5 details the motivational factors of women migrant entrepreneurs in UAE with $60 \%$ citing their main motive to setting up a business as the desire for independence. 
Table 5 Motivational factors

\begin{tabular}{lcc}
\hline Motivational factors & Push/Pull & Percentage \\
\hline Desire for independence & Pull & $60 \%$ \\
Willingness to take responsibility & Push & $45 \%$ \\
Work and family balance & Pull & $45 \%$ \\
Influenced by market opportunity (or less opportunity) & Push & $42 \%$ \\
Inspiration from successful entrepreneurs & Pull & $11 \%$ \\
To be challenged intellectually & Pull & $10 \%$ \\
\hline
\end{tabular}

For instance, the owner of a Furniture Interiors Company says,

"income is an important factor but independence and pursuing my passion is more important than the income."

According to another woman entrepreneur who is part of her family business and unmarried,

"Work is much of a priority at this stage of life. It has taught me to take decisions, manage resources and be independent."

She also feels she is able to contribute to the business by bringing in new ideas into the organisation and modernising the family business.

$45 \%$ have taken up self-employment for better work and family balance. They agreed that the family factor could be considered to add on their pull motivation factors and not push as they were not being pushed by the family's economic necessity but to help them in their willingness to take responsibility.

"I was not taught to be the head of the house but instead to support. My hobby helps to bring extra money in the house which I can invest for future" says a beauty parlour owner who created the business out of her hobby and which in turn provides the financial support to her family. She also says "work-life balance is important because money is of no use if there is no family to go home to."

Another entrepreneur who runs a tuition centre says

"my daughter is a teen which is all the more important for me to focus on her studies more than my career."

For many of these women, family takes priority over career.

Family and support from friends seem to be the major reason for the women to have started and continued in their own venture. $91 \%$ of the target women stated that had it not been for their family or close friends, they would not have been able to initiate or continue with their venture. The family is an important financial and human resource for the entrepreneur and utilisation of this resource makes the business more successful (Butler, 1991) and is also associated with long-term growth (Upton and Heck, 1997). What was interesting to note that almost $100 \%$ of the respondents had an entrepreneur in the immediate family/social circle, but only $10 \%$ of them were women, $25 \%$ also stated their father/brother/uncle as a role model for becoming an entrepreneur.

Four among the thirteen women entrepreneurs, however, mentioned a neutral stance taken by family members. Women entrepreneurs consider their families as important support providers; however, conflicts often occur between work and family due to time 
constraints (Erogul and McCrohan, 2008). To avoid this, a woman who is a business partner along with her husband for printing company comments "it is important to be able to balance work and family and I am able to do it since I work along with my husband" and she recommends it to families who have their own business.

According to the study by Daly (1991) it was found that women with children are more likely to be self-employed. Also marriage seems to provide support in establishing a successful enterprise. According to Marlow (1992), migrant entrepreneurs do not appear to benefit from, or even use, formal networks, which is an important obstacle to business formation and growth. These entrepreneurs generally have fewer opportunities to develop relevant experience, have fewer contacts and have greater difficulty information resources in a majority-dominated environment (Brush and Vanderwerf, 1992; Carter and Rose, 1998).

One of the biggest factors that motivated the entrepreneurs was not financial instability but the willingness to turn a hobby into a source of income. Many among these women entrepreneurs during the interview stated that they started their business so that they could work for themselves while many also suggested that entrepreneurship was a way to turn their hobby into something bigger. Two of the women got into social entrepreneurship as they felt that there is huge scope of social development in the region.

$42 \%$ of the migrant women entrepreneurs' feel they have been pushed into self employment due to challenges in the environment. In a study by Yaseen (2013), it was stated that women face a lot of barriers that may include inhospitable organisational culture, organisational barriers, biased promotion decisions, work-home conflicts, personal and family barriers. Also lack of recognition and support by male CEOs, male mentors and emotional and interpersonal support may push women into entrepreneurship. Although the findings of the current study concur with the earlier research that suggests that economic necessities or 'better income' were important for only $2 \%$ of the women entrepreneurs, almost $15 \%$ also considered 'no other job opportunity' and $3 \%$ of them job loss as the factors pushing them towards entrepreneurship. On probing this percentage of the women further, it was found that many considered the opportunities available in the market to have pushed them and that they were motivated by the positive market trends in the UAE. For instance an entrepreneur who runs a day-care centre for children feels that she has found an opportunity in terms of a large migrant population here where both parents are working. She also feels her motivation is not about money but being able to help other families by taking care of their child in the day care. The perception of these women were that the environment did push them into entrepreneurship as it provided them with the 'opportunity' and would therefore rather associate themselves being 'pulled' towards entrepreneurship instead of being pushed due to economic necessity.

\section{Conclusions}

This paper has been a preliminary investigation of the motivations and personality characteristics of women entrepreneurs. The findings suggest the importance of push as well as the pull factors, and the influence of the personal characteristics in the formation of a new business. While majority of the survey results suggest more of pull factors than push, Hughes (2003) raises a pertinent question on the correct interpretation of push and pull. 'A desire for independence', for example, may reflect a positive attraction to self-employment (a pull) or a rejection of a lack of independence in prior work (a push). 
Therefore in the present study we have explored the perspectives of 13 entrepreneurs on push-pull factors according to the respondent's viewpoints and future studies could be taken with a larger representative sample.

The theoretical contribution of this paper is that it adds to the literature of migrant women entrepreneurship. The importance of identities in terms of either gender or nationality is highlighted in the context of UAE and we have seen the motivating factors for this section of entrepreneurs. Our research found that the primary motivation factor driving women to start their own business is their desire to turn their hobby into a source of income and become independent. One of the important findings was the role of family in formation of the business as majority of the women were looking to balance their work-life. By exploring the motivations and characteristics that impact the business performance of women migrant entrepreneurs, we aim to enrich understanding on migrant women entrepreneurs in UAE.

The study has apparent limitations, one of them being the small sample size due to which the results cannot be construed as indicative and representative of the entire migrant women population in UAE. The sample was too small to completely represent the population of migrant women entrepreneurs in UAE and hence it inhibits generelisabity (Lewis, 2013; Chandler and Hanks, 1994). Nevertheless it has assisted in understanding the motivational factors and the characteristics for women entrepreneurship. Although the insights provided by these 29 entrepreneurs provide only a partial picture, it is hoped that this exploratory study will help in the literature of migrant women entrepreneurship, and be a foundation for future studies on interrogating the migrant's issues and entrepreneurial characteristics. Some of the future areas of research could be to find the level of contribution to the industry and economy made by this segment of women entrepreneurs through their input, the importance of network relations in a migrant community and the role of family members in establishment and operation of the venture.

\section{References}

Aldrich, H.E. (1989) 'Networking among women entrepreneurs', in Hagen, O., Rivchum, C. and Sexton, D. (Eds.): Women-Owned Businesses, pp.103-132, Praeger, New York.

Aldrich, H.E. and Zimmer, C. (1986) 'Entrepreneurship through social networks', in Sexton, D.L. and Wilson, R.W. (Eds.): The Art and Science of Entrepreneurship, pp.154-167, Ballinger, Cambridge, MA.

Brockhaus, R.H. (1982) 'The psychology of the entrepreneur', in Kent, C.A., Sexton, D.L. and Vesper, K.L. (Eds.): Encyclopedia of Entrepreneurship, Prentice Hall, Englewood Cliffs, NJ.

Brooke, R.E. and Margaret, L. (1998) 'Behaviors of entrepreneurs: a gender comparison', Journal of Business and Entrepreneurship, Vol. 6, No. 1, pp.106-115.

Brush, C.G. and Hisrich, R.D. (1991) 'Antecedent influences on women-owned businesses', Journal of Managerial Psychology, Vol. 6, No. 2, pp.9-16.

Brush, C.G. and Vanderwerf, P.A. (1992) 'A comparison of methods and sources for obtaining estimates of new venture performance', Journal of Business Venturing, Vol. 7, No. 3, pp.157-170.

Butler, J.S. (1991) Entrepreneurship and Self-Help among Black Americans: A Reconsideration of Race and Ethnicity, State University of New York Press, New York.

Carland, J. and Carland, J.C. (1993) 'The role of personality in new venture creation', Entrepreneurship, Innovation and Change, Vol. 2, No. 2, pp.129-140. 
Carter, S. and Rose, P. (1998) 'The financing of male and female-owned businesses', Entrepreneurship and Regional Development, Vol. 10, No. 3, pp.225-241.

Carter, S.L. and Jones-Evans, D. (2006) Enterprise and Small business: Principles, Practice and Policy, 2nd ed., Harlow, UK.

Chandler, G.N. and Hanks, S.H. (1994) 'Market attractiveness, resource-based capabilities, venture strategies, and venture performance', Journal of Business Venturing, Vol. 9, No. 4, pp.331-349.

Chavan, M. (2011) 'Framework identifying the heterogeneous resource constraints faced by women entrepreneurs at the planning and managing stages', International Journal of Interdisciplinary Social Sciences, Vol. 6, No. 2, pp.1-22.

Cook, J. (1982) 'Women: the best entrepreneurs', Canadian Business, June, pp.68-73.

Daly, M. (1991) 'The 1980s, a decade of growth in enterprise', Employment Gazette, Vol. 99, No. 3, pp.109-134.

Dechant, K. and Al-Lamky, A. (2005) 'Towards an understanding of Arab women entrepreneurs in Bahrain and Oman', Journal of Developmental Entrepreneurship, Vol. 10, No. 2, pp.123-140.

Ehigie, B.O. and Umoren, U.E. (2003) 'Psychological factors influencing perceived entrepreneurial success among Nigerian women in small-scale businesses', Journal of International Women's Studies, Vol. 5, No. 1, pp.77-94.

Erogul, M.S. and McCrohan, D. (2008) 'Preliminary investigation of Emirati women entrepreneurs in the UAE', African Journal of Business Management, Vol. 2, No. 10, pp.177-185.

Essers, C. and Benschop, Y. (2007) 'Enterprising identities: female entrepreneurs of Moroccan and Turkish origin in the Netherlands', Organization Studies, Vol. 28, No. 1, pp.49-69.

Essers, C. and Benschop, Y. (2009) 'Muslim businesswomen doing boundary work: the negotiation of Islam, gender and ethnicity within entrepreneurial contexts', Human Relations, Vol. 62, No. 3, pp.403-424.

Essers, C. and Tedmanson, D. (2014) 'Upsetting 'others' in the Netherlands: narratives of Muslim Turkish migrant businesswomen at the crossroads of ethnicity, gender and religion', Gender, Work \& Organization, Vol. 21, No. 4, pp.353-367, doi:10.1111/gwao.12041.

Fagenson, E.A. and Marcus, E.C. (1991) 'Perceptions of the sex-role stereotypic characteristics of entrepreneurs: women's evaluations', Entrepreneurship Theory and Practice, Vol. 15, No. 4, pp.33-47.

Gatewood, E., Shaver, K. and Gartner, W. (1994) 'A longitudinal study of cognitive factors influencing start-up behaviours and success at venture creation', Journal of Business Venturing, Vol. 10, No. 5, pp.371-391.

Goby, V.P. and Erogul, M.S. (2011) 'Female entrepreneurship in the United Arab Emirates: legislative encouragements and cultural constraints', Women's Studies International Forum, Vol. 34, No. 4, pp.329-334. doi:10.1016/j.wsif.2011.04.006.

Gulf Business (2014) [online] http://gulfbusiness.com/2014/01/new-initiative-launched-supportfemale-entrepreneurs/\#.VIGriTGUeHE (accessed 24 March 2016).

Haan, H.C. (2004) Small Enterprises: Women Entrepreneurs in the UAE, Centre for Labour Market Research and Information, Tanmia/CLMRI, Dubai, UAE.

Hansemark, O. (1998) 'The effects of an entrepreneurship programme on need for achievement and locus of control of reinforcement', International Journal of Entrepreneurial Behaviour and Research, Vol. 4, No. 1, pp.28-50.

Hisrich, R.D. and Peters, M.P. (1996) Entrepreneurship: Starting, Developing and Managing a New Enterprise, Irwin, Illinois.

$\backslash$ Ho, T.S. and Koh, H.C. (1992) 'Differences in psychological characteristics between entrepreneurially-inclined and non-entrepreneurially-inclined accounting graduates in Singapore', Entrepreneurship, Innovation and Change: An International Journal, Vol. 1, No. 2, pp.243-254. 
Hughes, K.D. (2003) 'Pushed or pulled? Women's entry into self-employment and small business ownership', Gender, Work \& Organization, Vol. 10, No. 4, pp.433-454, doi:10.1111/14680432.00205 .

Hwang, D., Staley, B., Chen, Y. and Lan, J. (2008) 'Confucian culture and whistle blowing by professional accountants: an exploratory study', Managerial Auditing Journal, Vol. 23, No. 5, pp.504-526.

Jenkins, S.P. (1984) Winners and Losers: A Portrait of the UK Income Distribution During the 1980s, Swansea Department of Economics, Discussion Paper No. 94-97.

Johnson, B.R. (1990) 'Toward a multidimensional model of entrepreneurship: the case of achievement motivation and the entrepreneur', Entrepreneurship Theory and Practice, Vol. 14, No. 3, pp.39-54.

Klyver, K. and Terjesen, S. (2007) 'Entrepreneurial network composition: an analysis across venture development stage and gender', Women in Management Review, Vol. 22, No. 8, pp.682-688.

Kuratko, D.F. (2008) Entrepreneurship: Theory, Process, and Practice, 8th ed., Cengage Learning, South-Western College Publishing, Cincinnati, $\mathrm{OH}$.

Langevang, T. and Gough, K.V. (2012) 'Diverging pathways: young female employment and entrepreneurship in Sub-Saharan Africa', Geographical Journal, Vol. 178, No. 3, pp.242-252, doi:10.1111/j.1475-4959.2011.00457.x.

Lewis, P. (2013) 'The search for an authentic entrepreneurial identity: difference and professionalism among women business owners', Gender, Work \& Organization, Vol. 20, No. 3, pp.252-266, doi:10.1111/j.1468-0432.2011.00568.x.

Madichie, N.O. (2009) 'Breaking the glass ceiling in Nigeria: a review of women's entrepreneurship', Journal of African Business, Vol. 10, No. 1, pp.51-66, doi:10.1080/ 15228910802701361.

Mani, C. (2011) 'Forces behind entrepreneurship of women - an economic study', International Journal of Bio-Resource \& Stress Management, Vol. 2, No. 3, pp.355-358.

Marlow, S. (1992) 'The take-up of business growth training schemes by ethnic minority-owned firms in Britain', International Small Business Journal, Vol. 10, No. 4, pp.34-47.

McAdams, R.H. (1997) 'The origin, development, and regulation of norms', Michigan Law Review, Vol. 96, p.338 [online] http://chicagounbound.uchicago.edu/journal_articles?utm source=chicagounbound.uchicago.edu\%2Fjournal_articles\%2F1655\&utm_medium=PDF\&ut m_campaign=PDFCoverPages (accessed 12 February 2015).

McClelland, D.C. (1961) The Achieving Society, Van Nostrand, New York.

McGrath Cohoon, V.W. (2010) The Anatomy of an Entrepreneur, Are Successful Women Entrepreneurs Different From Men?, Issue Brief, Kauffman Foundation, Kansas City, USA.

Miner, J.B., Smith, N.R. and Bracker, J.S. (1989) 'Role of entrepreneurial task motivation in the growth of technologically innovative firms', Journal of Applied Psychology, Vol. 74, No. 4, pp.554-560.

Minniti, M. and Naudé, W.A. (2010) 'What do we know about the patterns and determinants of female entrepreneurship across countries?', The European Journal of Development Research, Vol. 22, No. 3, pp.277-293.

Oinas, P. (1999) Unpacking 'Embeddedness', mimeo.

Osirim, M.J. (2008) 'African women in the new diaspora: transnationalism and the (re)creation of home', African \& Asian Studies, Vol. 7, No. 4, pp.367-394, doi:10.1163/156921008X359588.

Ramaswamy, G. (2013) 'Psychosocial and psycho-entrepreneurial predictors - an exploratory study on Indian women entrepreneurs', Women's Studies, Vol. 42, No. 2, pp.163-192, DOI: $10.1080 / 00497878.2013 .747380$.

Roomi, M.A. and Parrot, G. (2008) 'Barriers to development and progression of women entrepreneurs in Pakistan', The Journal of Entrepreneurship, Vol. 17, No. 1, pp.59-72. 
Saffu, K. (2003) 'The role and impact of culture on South Pacific Island entrepreneurs', International Journal of Entrepreneurial Behaviour and Research, Vol. 9, No. 2, pp.55-73.

Sahin, M., Nijkamp, P. and Rietdijk, M. (2009) 'Cultural diversity and urban innovativeness: personal and business characteristics of urban migrant entrepreneurs', Innovation: The European Journal of Social Sciences, Vol. 22, No. 3, pp.251-281, doi:10.1080/ 13511610903354364.

Salmenniemi, S., Karhunen, P. and Kosonen, R. (2011) 'Between business and byt: experiences of women entrepreneurs in contemporary Russia', Europe-Asia Studies, Vol. 63, No. 1, pp.77-98, doi:10.1080/09668136.2011.534304.

Sapuan, D.A., Yusof, M. and Nor, L.M. (2009) 'Single mothers: breadwinners, their gender roles and entrepreneurial characteristics', UNITAR E-Journal, Vol. 5, No. 2, pp.48-60.

Sardar, Z. (2005) Desperately Seeking Paradise: Journeys of a Sceptical Muslim, Granta, London.

Schwartz, E. (1976) 'Entrepreneurship: the new female frontier', Journal of Contemporary Business, Winter, Vol. 5, pp.47-76.

Schwer, R.K. and Yucelt, U. (1984) 'A study of risk-taking propensities among small business entrepreneurs and managers: an empirical evaluation', American Journal of Small Businesses, Vol. 8, No. 3, pp.31-40.

Shane, S. (1996) 'Explaining variation in rates of entrepreneurship in the United States: 1899-1988', Journal of Management, Vol. 22, No. 5, pp.747-781.

Shaver, K.G. and Scott, L.R. (1991) 'Person, process, choice: the psychology of new venture creation', Entrepreneurship Theory and Practice, Vol. 16, No. 2, pp.23-45.

Simsek, M. and Uzay, N. (2009) 'Economic and social problems of women entrepreneurs and Turkey application', Journal of Academic Research in Economics, Vol. 1, No. 3, pp.289-307.

UAE Interact (2013) [online] http://www.uaeinteract.com/docs/UAE_a_popular_migrant destination_UN_report/57082.htm (accessed 28 January 2015).

UAE Interact (2015a) [online] http://www.uaeinteract.com/docs/Report_on_Womens Empowerment_in_the_UAE/68158.htm (accessed 18 October 2015).

UAE Interact (2015b) [online] http://www.uaeinteract.com/society/women.asp (accessed 18 October 2015).

Upton, N.B. and Heck, R.K.Z. (1997) 'The family business dimensions of entrepreneurship', in Sexton, D.L. and Smilor, R.W. (Eds.): Entrepreneurship 2000, pp.243-266, Upstart, Chicago, IL.

Wolcott, H. (1990) 'On seeking - and rejecting - validity in qualitative research', in Eisner, E.W. and Peshkin, A. (Eds.): Qualitative Inquiry in Education: The Continuing Debate, pp.121-152, Teachers College Press, New York.

World Bank (2016) Doing Business 2016: Measuring Regulatory Quality and Efficiency, World Bank, Washington, DC DOI: 10.1596/978-1-4648-0667-4, License: Creative Commons Attribution CC BY 3.0 IGO [online] http://www.doingbusiness.org/ /media/GIAWB/ Doing\%20Business/Documents/Annual-Reports/English/DB16-Full-Report.pdf (accessed 12 February 2016).

Yaseen, Z.K. (2013) 'Women entrepreneurs: challenges and opportunities in the Arab world, UAE case', Business \& Entrepreneurship Journal, Vol. 2, No. 1, pp.43-48. 